\title{
Communicating Corporate Social Responsibilities: Using Text Mining for a Comparative Analysis of Banks in India and Ghana
}

\author{
Anusua Saha \\ Tomas Bata University in Zlin, Faculty of Management and Economics, Mostni 5139, 76001 Zlin, Czech Republic \\ anusua08@yahoo.com \\ Stephen Nabareseh \\ Tomas Bata University in Zlin, Faculty of Management and Economics, Mostni 5139, 76001 Zlin, Czech Republic \\ nabareseh@fame.utb.cz
}

\section{Doi:10.5901/mjss.2015.v6n3s1p11}

\begin{abstract}
The increasing importance of corporate social responsibility (CSR) to entrepreneurial policies has created a vast array of research concern all over the world. The strategic integration of CSR in the core business of companies shows the bilateral relation between the company and the community the company serves in. Sustainability reports are recognized worldwide as a tool that companies use to communicate their socially responsible behavior. The objective of this paper is to analyze companies' behavior towards CSR based on their disclosure practices. The study uses the CSR reports of four banks each from India and Ghana for 2013 in the comparative analysis. The paper compares the CSR activities between the two emerging economies with the use of the text mining technique of data mining. It was realized from the comparison that both countries have different focus areas although some of their CSR activities are quite similar.
\end{abstract}

Keywords: Sustainability report, Corporate Social Responsibility, Banking sector, Stakeholders, India, Ghana

\section{Introduction}

The strategic integration of CSR in the core business of companies shows the bilateral relation between the company and the community the company operates. The means of communication between the company and its stakeholders with its disclosure of social and environmental information in annual reports, sustainability report and on websites is gaining importance (KMPG, 2011). Sustainability Report (SR) is the tool used mostly by companies to present their economic, environmental and social impact. The levels of SR disclosure and its credibility are linked to the reasons underlying the CSR policies adopted. Graafland and Smid (2004) argue that greater communication about social behavior is necessary to improve companies' reputation. Nielsen and Thomsen (2007) affirm that from a managerial perspective, non-financial reporting looks for transparency in social behavior when communicating corporate activities with social and environmental effects. Cornelissen (2004) posits that a firm's future depends on how the key stakeholders perceive the firm's behavior. Therefore, sustainability reports can be considered as the public expression of socially responsible behavior. In fact, sustainability report is a way to connect with stakeholders, to show how companies are doing and to set examples for others (European Commission, 2005).

Nowadays, the societal expectations about the responsible role of business in society are on the increase. The increase in research on corporate social responsibility discourse shows that there have been developments of a variety of instruments that aim to improve, evaluate and communicate socially responsible practices. Concerns about CSR dominate the socio-economic landscape (Jones, Frost, Loftus, \& van der Laan, 2005, 2007) of the globe. One issue of increasing importance is the need to recognize industry specificity when formulating and assessing CSR disclosure. The Global Reporting Initiative (GRI) has commenced the production of industry-specific guidelines for CSR reporting (GRI, 2006). In a similar vein, academic research on CSR disclosure is urged to recognize the impact of industry sector and sub-sector specificity (Aerts et al., 2006; Burritt \& Welch, 1997; Guthrie et al., 2008; Jones et al., 2007). Indeed, Patten (2002) attributes the equivocal findings by studies examining the relationship between environmental disclosure and performance to a failure to appropriately control industry classification.

Prior studies found that higher levels of CSR disclosure occur concurrently with increased attention and focus on a company's environmental problems, greater threats of litigation and fines, and prominent stakeholder groups 
(O'Donovan, 2002). A number of studies have identified the nature of a company's industry as a factor affecting CSR disclosure (Cho \& Patten, 2007; Halme \& Huse, 1997; Patten, 1991; Roberts, 1992; Yongvanich \& Guthrie, 2005). These studies argue that companies in different industries have differing motivations towards legitimation. These studies generally find that companies in industries with a higher social and environmental impact or profile engage in higher levels of CSR disclosure compared to their counterparts in other industries. However, studies by Campbell et al (2003) and de Villiers \& van Staden (2006) contradict the above results. The authors' found that companies in industries that have less environmental impact and apparent legitimacy gaps often engage in higher levels of disclosure. Because legitimacy theory is based on perceptions, for remedial action to have an effect on external parties, it must be accompanied by public disclosure (Cormier \& Gordon, 2001).

For corporations, the adoption of CSR strategies can enhance their relationships with stakeholders. It is necessary to communicate CSR activities and use effective relationship management to satisfy stakeholders' expectations and achieve the expected goals of CSR initiatives (Clarke, 2000; Podnar, 2008). To date, there have been several studies examining the practices and communication of CSR in different industries (Chen \& Bouvain, 2009; Sweeney \& Coughlan, 2008). However, the comparative study of CSR reports/disclosure of Banks and other cooperate companies has been scarce in research. This paper employs the text mining algorithm of data mining to identify interestingness measures that portray differences and similarities of CSR initiatives in the 2013 annual reports of selected Banks in India and Ghana. The objective of this paper is to analyze companies' behavior towards CSR based on their disclosure practices. The paper sets to achieve the objective of identifying similarities and differences of CSR activities by selected banks in the two countries. This will open up significant areas for adoption and improvement of CSR activities where there is the need from the results of the study. The significance of the results also lie squarely with policy makers and other formulators in their regional evaluation of CSR activities in the quest to formulate new policies.

\section{Overview of Banks in India and Ghana}

Financial system is the backbone of any economy as it has direct bearing on the economic growth of a country and thereby prosperity and welfare of the population. Stability of the financial system is critical to the stability of the economy. The banking sector is the principal constituent of the financial system. A strong and resilient banking system is the foundation for sustainable economic growth. The basis for efficient banking is simplicity in operations based on effective risk management, transparency and accountability. A brief review of the banking industry in the two countries is detailed below.

\subsection{Indian Banking system}

India is considered among the top economies in the world with tremendous potential for its banking sector to flourish. The banking sector in India is a tightly regulated industry that is guided by the policies of the central bank, the Reserve Bank of India (RBI). Considered to be a conservative system, the banking sector saw the entry of private players and foreign banks after the opening up of Indian economy after 1992. Presently, the banking industry in India is a mixture of public, private and foreign ownerships. The last decade witnessed a significant upsurge in transactions through ATMs, internet and mobile banking. The style of operation is slowly evolving with the integration of modern technology into the banking industry. In the next 5-10 years, the sector is expected to create up to two million new jobs driven by the efforts of the RBI and the Government of India to expand financial services into rural areas. The market size of banking assets in India is totaled US\$ 1.8 trillion in FY 13 and is expected to touch US\$28.5 trillion in FY 25. Bank deposits have grown at a compound annual growth rate (CAGR) of $21.2 \%$ over FY 06-13. In FY 13, total deposits were US\$ 1,274.3 billion. The revenue of Indian banks increased from US\$ 11.8 billion to US\$ 46.9 billion over the period 2001-2010. Profit after tax also reached US\$ 12 billion from US\$ 1.4 billion during this period (IBEF, 2012).

India's banking industry could become the fifth largest banking sector globally by 2020 and the third largest by 2025. These days, banks in India are turning their focus to servicing clients and improving their technology infrastructure, which can help better customer experience and give them a competitive edge. These measures created a competitive environment in the banking system which in turn facilitated lowering of interest rates and interest spread in line with international standards. The emphasis is on structural measures, improvement in disclosure standards and level of transparency with an aim to align Indian banking standards with internationally recognized best practices (Mohan, 2005). 


\subsection{Ghanian Banking system}

The financial sector in Ghana is facing enormous development to support the economic growth of the Country. There is a continuous increase in non-banking financial institutions with an influx in rural and community banking (Addeah, 1989; Anim, 2000). Bank of Ghana (2014) reported that the banking industry has remained very profitable and liquid through the years. The pillars of initiating these changes in the industry hinge on the increment in the use of information technology equipment (eBanking, debit and credit cards) (Abor, 2005), deregulation of financial services and effects from global financial activities. The introduction of these changes and deregulation process has opened the sector for foreign competition and entrance of both local and multinational foreign banks (Brownbridge \& Gockel, 1996).

The banking sector in Ghana is inundated with competition from local and multinational foreign banks (Bawumia \& Abradu-Otoo, 2003). This competition has increased quality in financial transactions, corporate social responsibilities and corporate governance. Recently, some banks in the Country have merged to maximize profit and become efficient in competing with foreign banks. Most banks have also cut operational cost to increase and retain customers (Bawumia, 2007). There is an influx of foreign banks into the country especially from Asia (China and India). There has been several collaboration of local banks with foreign banks. The unbanked population of Ghana has reduced drastically over the years (Daniel \& Jonathan, 2013).

The growth of the economy and the increase in the middle class has resulted in the robustness of the economy and the interest of foreign banks in the financial market of the country. India has established two banks so far in Ghana, Bank of Baroda and $\mathrm{ICICl}$ bank which collaborates with Ecobank Ghana. With the introduction of the risk based supervision by the Bank of Ghana and the re-capitalization process currently in place (Daniel \& Jonathan, 2013), quality of service in banks is on the rise. CSR activities have presented an avenue of competition and a tool in attracting customers. The increment of the minimum capital requirement will also reduce the risk in the rate of default by banks.

\section{Research Methodology}

Four banks each from India (State Bank of India, Industrial Credit and Investment Corporation of India, Punjab National Bank, HDFC bank) and Ghana (EcoBank Ghana, Ghana Commercial Bank, Standard Chartered Bank Ghana, Fidelity Bank) were selected for the study. Ranking of the banks per their market share in the respective countries was considered as the first criteria in selecting the banks. The other criteria also adopted is the availability of 2012 and 2013 CSR or sustainability reports of the bank. The two Countries were chosen because they are both Lower Middle Income Economies based on the World Bank ratings. India is also the second highest investment country in Ghana investing over one billion dollars in various industries.

The CSR reports of the selected banks are extracted from the internet. Content analysis is done on the banks reports for similarities and differences to identify interestingness. Other survey reports on banking are analyzed based on the market share of the selected banks. Text mining is one novel data mining algorithm adopted by many researchers lately to analyse textual data. Text mining is then applied on the textual data to discover patterns and trends in the CSR reports of the banks. This methodology is particularly selected since it elicits trends and patterns within voluminous textual data that might be cumbasome to analyse with other analytical tools. Since the study is particularly interested in interestingness, patterns and trends in CSR reports of banks in the two countries, text mining becomes a handy and ideal tool and method to adapt. The rest of the paper is arranged as in figure 1 below:

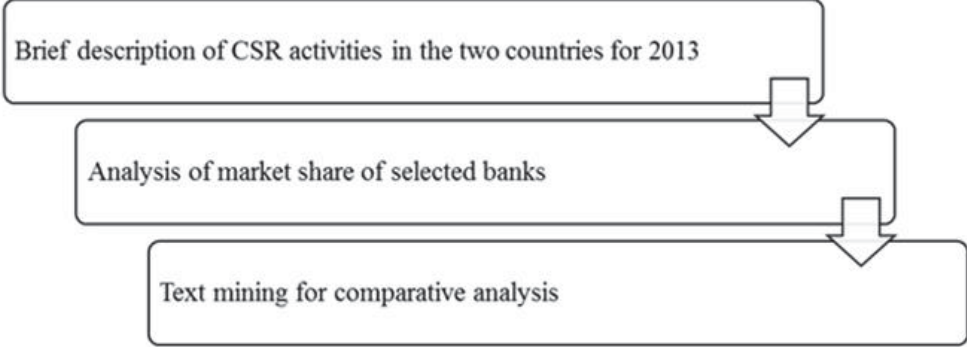

Figure 1. Outline of the Study 


\subsection{CSR activities for 2013 in two countries}

\subsubsection{Indian selected banks}

a. State Bank of India (SBI)

The focus areas of the Bank's CSR activities are supporting education, supporting healthcare, assistance to poor \& underprivileged, environmental protection, entrepreneurial development programmes and help in natural disaster occurrences. The bank also undertook the activity known as caring for Environment. This is a wind based power project to generate power for the bank branches in the states of Maharshtra, Gujrat and Tamil Nadu. Among many CSR initiatives undertaken during the financial year, the Company extended educational support towards under privileged children across the country, partnering with its CSR partner 'Smile Foundation'.

SBI Life's corporate ethos is about giving back to the society with the objective of making a difference in the lives of the needy. SBI Life has undertaken various CSR projects during the year under review. Tree plantation drive witnessed a plantation of 6,309 trees till date. "Gift a Smile" and "Project Scholar" are initiatives to contribute towards economically disadvantaged students. The bank took an initiative of supporting mentally challenged children of "Swayam Siddh". Donations have been made to Leprosy eradication centers. The Bank has initiated a pilot project to determine its carbon footprint levels, which will help in determining the Bank's resource consumption pattern and enable it take effective steps to implement various measures for sustainable usage in a cost effective way.

b. ICICl Bank

The banks CSR foundation focuses on the areas of elementary education, sustainable livelihoods, primary healthcare and financial inclusion. The Bank has been implementing programmes on behalf of the Government of India with the primary objective of reducing emissions and environmental pollution. The Bank supported initiatives in the area of clean technology and energy efficiency. Other CSR activities undertaken by the Bank within the period are

$>$ Invested in clean coal concepts like coal washers and cold bed methane for the first time in the country

$>$ Invested and played a significant role in the development of India's first electric passenger car in setting up the Bureau of Energy Efficiency

$>$ Supported setting up India's first centre to rate green buildings: the Confederation of Indian Industry Green Business Centre Hyderabad

$>$ Created consciousness amongst the employees on conserving energy across the offices and branches

$>$ Installed energy efficient air conditioners, LED lights, motion detector sensors and other energy conservation measures.

$>$ Soft loan/equity/grant assistance for development and assistance for development \& distribution of fuel efficient cook stoves \& solar lanterns, seed- stage sustainable energy and clean technology developments in health care and wildlife \& forest conservation.

C. Punjab National Bank (PNB)

PNB undertook some CSR activities aimed at empowering communities. Some of the activities included medical camps, health camps for farm animals, training and special visits of farmers to Agricultural Universities. Tree plantation camps, plantation along road sides, greening of traffic circles in different cities and maintenance of parks in residential areas are some of the initiatives the Bank undertook. The bank has also set up blood donation camps and adopted new born and malnutrition wards at Government Hospitals in Sikar and Rajasthan.

d. HDFC bank

The bank focused mostly on managing environmental impact through internal initiatives. These activities included issuing electronic transaction devices for corporate customers to reduce paper use, communicating with high net worth customers primarily through electronic media and encouraging retail customers to convert to e-statements instead of physical printouts. The bank has also adapted to Green Data Centers with State of the art technologies and renewable energy activities such as the use of solar ATMs.

The disposal of both solid and liquid waste has been part of the CSR activities of the bank. The bank liaises with waste disposal/recycling companies for recycling of paper and plastic. An electronic waste disposal policy has also be instituted by the bank to reduce the huge electronic waste generated by the bank. In its quest to enhance green economic issues, the bank purchases generators, energy electronic gadgets and air 
conditioners that are compliant with the norms of the Central Pollution Control Board. HDFC offers special schemes for farmers who take up organic farming projects and educate them on environmentally friendly methods of cultivation. Also as part of its CSR activities for 2013, the bank supported local communities by providing them with employment opportunities and conducting social awareness campaigns.

\subsubsection{Selected banks in Ghana}

a. EcoBank Ghana(EBG)

The Bank, according to Ecobank Ghana annual report (2013), promotes private sector involvement in renewable energy, green economy and removing electronic waste. The bank continues to apply the various steps in reducing electricity consumption and paper use to improve environmental performance and sustainability. The bank works with private organisations to reduce environmental risk in social sensitive sectors such as oil and gas, and mining. The bank in the year under review in partnership with Ghana Association of Bankers and the United Nations Environment Programme Finance Initiative (UNEPFI) organized a workshop on Environmental and Social Risk Analysis to imbue in its customers the skill of reducing environmental risk.

The banks focus areas in CSR activities are education, health, supporting the under-privileged, generating employment, and environmental protection. In 2013, EBG understook CSR activities such as EBG day celebration where the bank donated teaching and learning materials to over 25 schools across the country. Renovation of school buildings, provision of white boards, dual desk for students, computers and cleaning exercises was carried out. Other CSR activities carried out by the bank in the period included

- Donation to the Leukaemia foundation to help establish the facility for early detection and treatment of leukaemia.

- EBG supported the Domestic Violence and Victim Support Unit of the Ghana police Service in refurbishing the unit.

- The bank donated various items to three orphanages across the country.

- Other EBG's CSR activities in the period under review include the Larteh Water Project, Ghana Heart foundation, Ghana Cancer foundation, Korle Bu Teaching Hospital, some medical school students, Young Educators Foundation among others.

b. Ghana Commercial Bank (GCB)

Based on the GCB annual report (2013), the bank in 2013 carried out several CSR activities such as building of a two-unit classroom block to a deprived community. The building contained two classrooms, a sleeping room, a kitchen, bathroom and toilet for the nursery and kindergarten unit of the school. As part of its educational CSR policy, GCB donated some money to the two newly established public Universities in Ghana. The amount was to help in infrastructural development for the Universities. The bank also donated some amount to the Ghana Public Health Book Project to publish a book on Public Health in Ghana.

In the spirit of supporting physically challenged individuals, the bank continues to support a visually inspired student of the University of Ghana, Legon in diverse ways. The student has established a musical band which serves as an employment unit for others, hence the bank supported him to purchase musical instruments for the band.

c. Standard Chartered Bank Ghana (SCB-G)

The bank prioritized (Standard Chartered bank Ghana annual report, 2013) its CSR activities in 2013 to include educational support, environmental improvement, health care support (focusing on eye care), and the training of Coaches and physical education teachers all over the country.

d. Fidelity Bank (FB)

Over the years, the Bank has supported a number of institutions in health, education, sports among others. FB has supported many less privileged children in their education from the basic to the tertiary levels (Fidelity Bank Ghana annual report, 2013). The bank has also undertaken various sporting activities in collaboration with Tecno Mobile. The event created an avenue to select athletes for the development of athletics in Ghana.

\section{Findings and Discussion}

In considering the CSR activities of the banks of the two countries, we analyzed the market share of the countries for 
2013 based on research reports for the period. The text mining algorithm is used to compare the CSR reports of the two countries for interestingness patterns, similarities and differences.

\subsection{Market share analysis}

In figures 2 and 3 below, market share analysis for the two countries is presented. In figure 2, Ecobank Ghana Itd (EBG) topped all the banks by an increased market share of $12.9 \%$ for 2013 compared to 2012. The other three banks used for the study had a reduced market share in 2013 compared to the previous year. However, these banks still remained part of the top 10 banks in the country in terms of market share analysis (PWC, 2014).

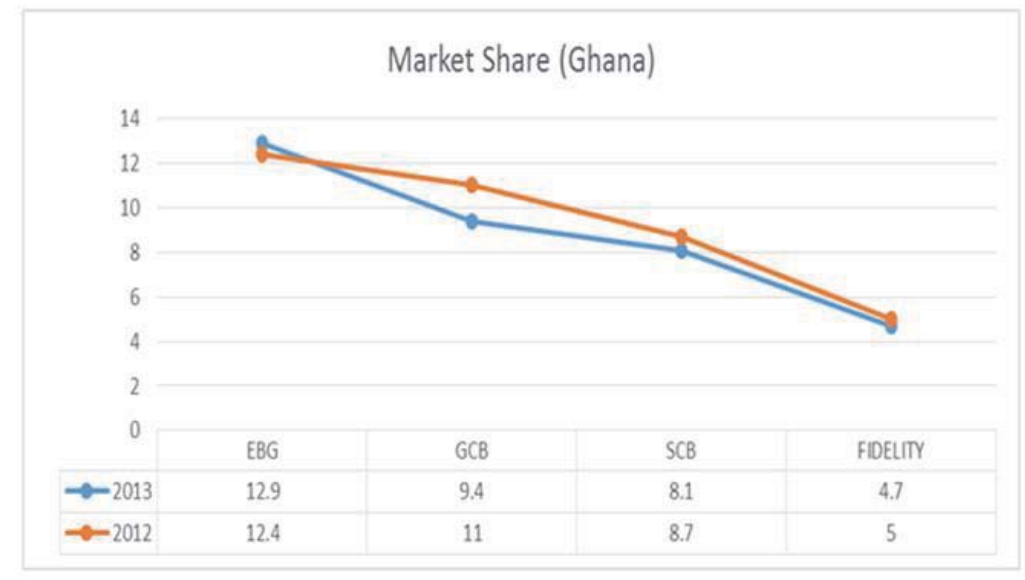

Figure 2. Market share of Ghanian Banks Source: 2014 Ghana Banking Survey

Figure 3 shows the market share of Indian banks selected for the study. SBI has the highest market share and has maintained this for the two years as seen in the figure below. PNB and HDFC had a reduction in their market share in 2013 as compared to 2012. These banks however still remained part of the top 5 banks in India resulting in their selection for the study.

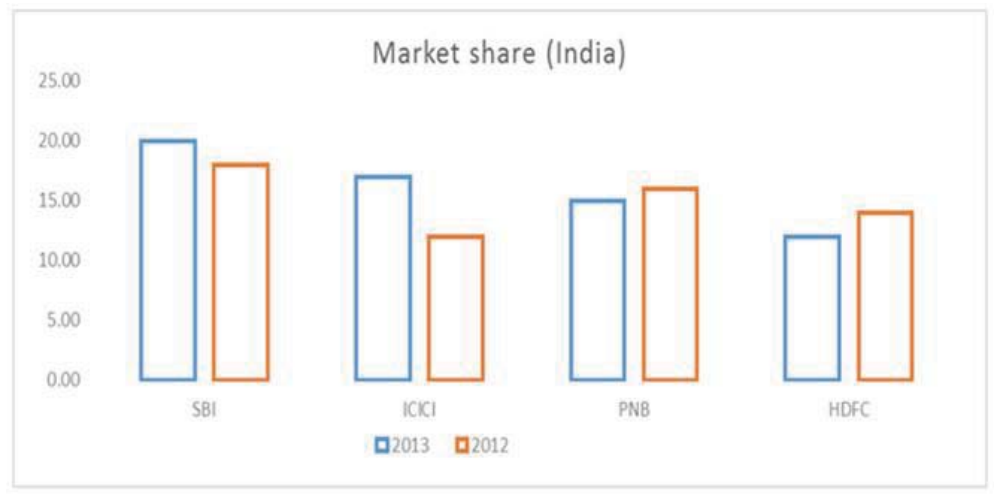

Figure 3. Market share of Indian banks Source: Companies annual reports

\subsection{Comparison using Text mining}

Text mining is a data mining technique used to analyze textual data to identify interestingness patterns in the text or assess similarities or difference between texts. In this paper, the $\mathrm{R}$ data mining tool is used with the text mining algorithm to analyze a corpus of CSR reports of the selected banks on country basis. Interestingness patterns and frequent words are then extracted from the transformed documents on separate country basis.

In the corpora of the Indian banks mined, the frequency of terms appearing for 50 or more times is presented 
below. Words such as assistance, clean, disposal, communities, environment, green, solar, waste, recycling and others can be seen. These words depict a summary of what the banks in India stand for in terms of CSR activities and what they are actually engaged in. Banks in India are undertaking community activities to save the environment and initiate green activities.
"across" "activities" "air" "also" "areas"
"assistance" "bank" "banks" "branches" "camps"
"centers" "centre" "children" "clean" "coal"
"communities" "conditioners" "conservation" "corporate" "country"
"csr" "customers" "development" "disposal" "education"
"effective" "efficiency" "efficient" "electronic" "energy"
"environment" "environmental" "farmers" "financial" "first"
"government" "green" "health" "healthcare" "help"
"included" "indias" "initiatives" "invested" "measures"
"objective" "paper" "part" "plantation" "pollution"
"power" "primary" "programmes" "project" "projects"
"recycling" "reduce" "sbi" "setting" "solar"
"special" "states" "supported" "supporting" "sustainable"
"take" "technology" "towards" "tree" "undertaken"
"undertook" "use" "various" "waste" "year"

The wordcloud in figure 4 below displays how related the frequent words are and depicts the words that appear more in the corpus. It is seen that green, sustainable, waste, disposal and other words are so related. It can be concluded that Indian banks are more focused on environmental protection, green economic activities and the proper disposal of waste in communities in their CSR activities.

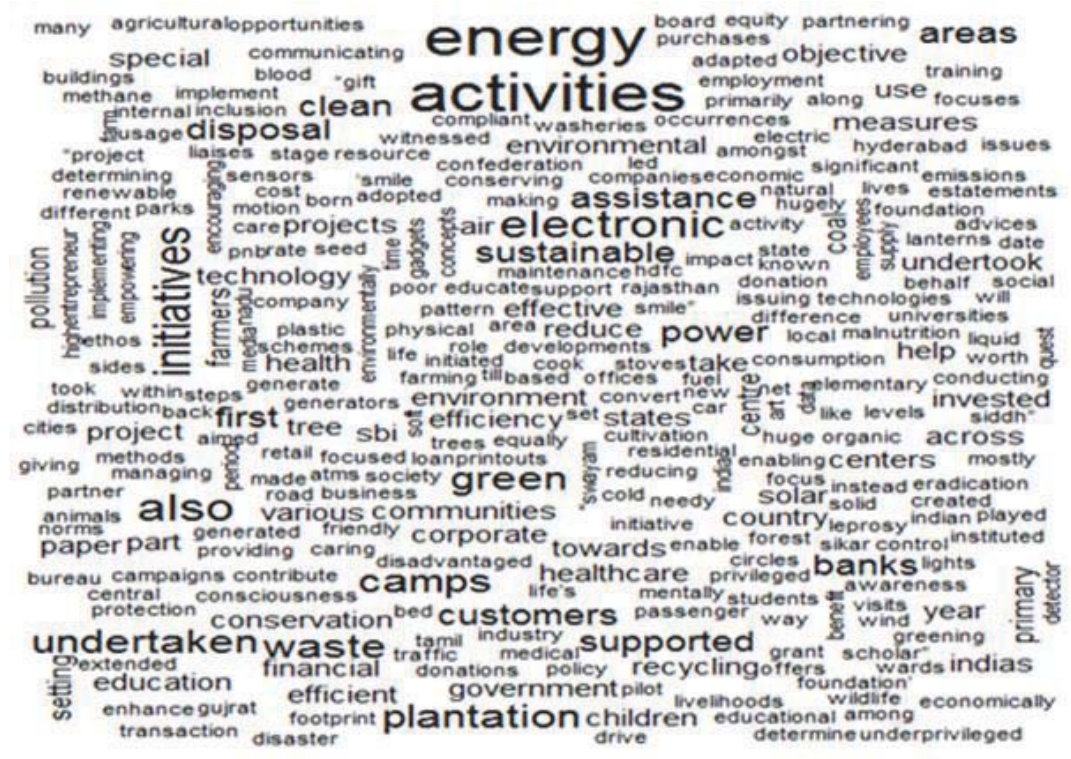

Figure 4. Wordcloud for CSR activities of Banks in India

Considering the selected banks in Ghana, text mining the corpus of CSR reports of these banks revealed frequent terms such as book, building, development, donated, education, environment, health, leukaemia, school, teaching, and universities among others. It is apparent from the frequent word list below that selected banks are more concentrated on educational activities for CSR. Some health activities such as donation to leukaemia centre, employment and development related activities can also be seen in the frequent word list below.

"across" "activities" "also" "among" "amount"

"band" "bank" "book" "building" "care"

"carried" "continues" "country" "csr" "development"

"donated" "ebg" "education" "educational" "employment" 
"environmental" "established" "foundation" "ghana" "health"

"help" "include" "leukaemia" "musical" "others"

"period" "private" "project" "public" "reducing"

"review" "risk" "school" "social" "students"

"support" "supported" "supporting" "teaching" "two"

"unit" "universities" "various"

In figure 5 below, the wordcloud shows the interrelation of words, appearance and concentration areas per the banks and their CSR activities. Once again, banks are into education, health and environmental CSR activities by supporting and donating to various schools and hospitals. The interestingness patterns of the frequency of terms appearing in the corpus of CSR reports from the selected banks is presented in the wordcloud in figure 4 below.

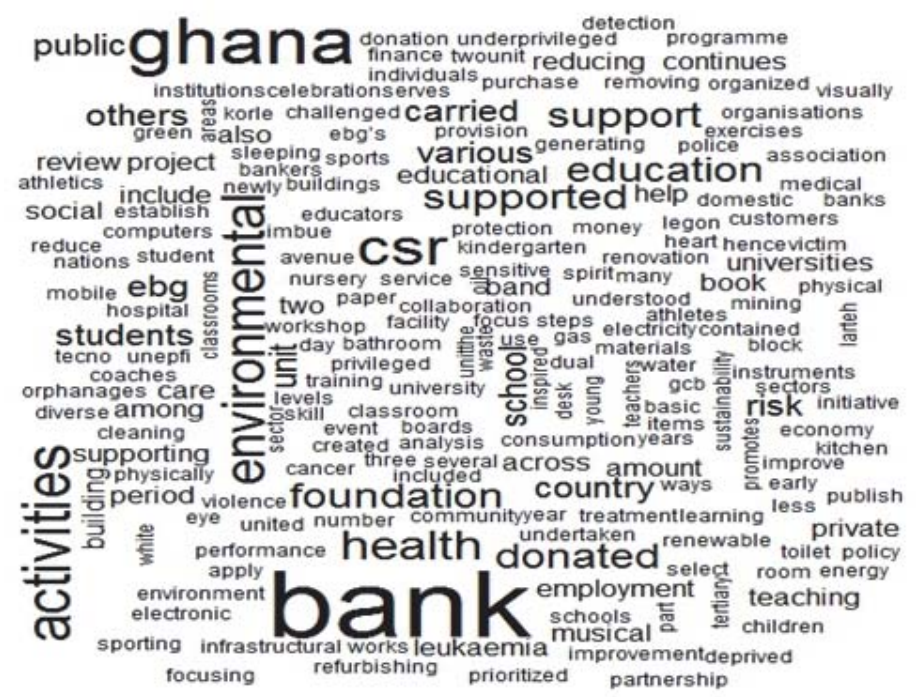

Figure 5. Wordcloud for CSR activities of Banks in Ghana

\section{Concluding Remarks}

This paper compares the CSR activities between two cultures with huge banking presence. Although the population of India far out-runs that of Ghana, the living conditions of citizens, especially in the rural areas are quite similar. The amenities needed by rural dwellers in these countries are comparable. The entrance of Indian banks in the financial market of Ghana, coupled with the number of both Ghanaian and Indian banks partnering each other justifies the comparative study of the CSR activities of the two countries.

From the analysis, it is observed that Indian banks are more into environmental and green development activities with much attention on reducing waste and disposal appropriately. Environmental and electronic waste pollution has engulfed Ghana (Brigden et al, 2008; Kuper and Hojsik, 2008) for many years now. Banks in Ghana can collaborate with their Indian counterparts to develop a special CSR policy on electronic waste to help fight the menace. Education is the bane for development (Tanner \& Bane, 1988) and responsible living. When education is spread to all in the rural areas, responsible living becomes part and parcel of their daily activities. The concentration of Ghanaian banks in education as a major feature of their CSR activity is quite commendable.

Although the selected banks in these two countries undertake some activities that are similar, the degree of engagement differs. It is not ruled out that selected Ghanaian banks undertake CSR activities in environmental protection, green economy and effective waste disposal, but the degree of engagement and magnitude of attention given the area is quite different from Indian banks. In a similar vein, selected banks in India also engage in educational and health related CSR activities, but the tempo of engagement and attention offered the sectors is much lower in comparison with their Ghanaian counterparts per the 2013 CSR reports of the selected banks of the two countries.

This research may help banks in the two countries and companies in developing countries in general collaborate in CSR activities in identifying the grey global areas that need more concentration for sustainable development. 


\section{Acknowledgement}

This work was supported by the Internal Grant Agency of Tomas Bata University in Zlin IGA/FaME/2014/007 and IGA/FaME/2013/035.

\section{References}

Abor, J. (2005). Technological innovations and banking in Ghana: an evaluation of customers' perceptions. IFE Psychologia: An International Journal, 13(1), p-170.

Addeah, K. (1989). An Introduction to the Law of Rural Banking in Ghana: Amantah Publications, Accra, Ghana.

Aerts, W., Cormier, D., \& Magnan, M. (2006). Intra-industry imitation in corporate environmental reporting: An international perspective. Journal of Accounting and public Policy, 25(3), 299-331.

Anim, T. E. (2000). Banking in Ghana. Accra, Ghana: Woeli Publishing Services, Accra, Ghana.

Bank of Ghana. (2014). Annual report 2013. Available at: http://www.bog.gov.gh/index.php?option=com_content\&view=article\&id=1734 \%3Aannual-report-2013\&catid=102\%3Aannual-reports\&ltemid=172. Accessed on 01/10/2014

Bawumia, M. (2007). Banking in Ghana in the Last 50 Years-Challenges and Prospects. A Keynote Address at the Launch of Ghana Banking Awards.

Bawumia, M., \& Abradu-Otoo, P. (2003). Monetary Growth, Exchange Rates and Inflation in Ghana: An Error Correction Analysis. Bank of Ghana (Working Paper).

Brigden, K., Labunska, I., Santillo, D., \& Johnston, P. (2008). Chemical contamination at e-waste recycling and disposal sites in Accra and Korforidua, Ghana.

Brownbridge, M., \& Gockel, A. F. (1996). The impact of financial sector policies on banking in Ghana. Institute of Development Studies, Accra, Ghana.

Burritt, R. L., \& Welch, S. (1997). Australian Commonwealth entities: an analysis of their environmental disclosures. Abacus, 33(1), 6987.

Campbell, D., Craven, B., \& Shrives, P. (2003). Voluntary social reporting in three FTSE sectors: a comment on perception and legitimacy. Accounting, Auditing \& Accountability Journal, 16(4), 558-581.

Chen, S., \& Bouvain, P. (2009). Is corporate responsibility converging? A comparison of corporate responsibility reporting in the USA, UK, Australia, and Germany. Journal of Business Ethics, 87(1), 299-317.

Cho, C. H., \& Patten, D. M. (2007). The role of environmental disclosures as tools of legitimacy: A research note. Accounting, Organizations and Society, 32(7), 639-647.

Clark, C. E. (2000). Differences between public relations and corporate social responsibility: An analysis. Public Relations Review, 26(3), 363-380.

Cormier, D., \& Gordon, I. M. (2001). An examination of social and environmental reporting strategies. Accounting, Auditing \& Accountability Journal, 14(5), 587-617.

Daniel, P. E. Z., \& Jonathan, A. (2013). Factors affecting the Adoption of Online Banking in Ghana: Implications for Bank Managers. International Journal of Business and Social Research, 3(6), 94-108.

De Villiers, C., \& Van Staden, C. J. (2006). Can less environmental disclosure have a legitimizing effect? Evidence from Africa. Accounting, Organizations and Society, 31(8), 763-781.

Ecobank Ghana Ltd, (2013). Ecobank Ghana Ltd Annual Report. Available at: http://www.ecobank.com/upload/201403291138579682 4fXBD4AFXTy.pdf. Accessed on 01/10/2014.

European Commission, 2005. A guide to communicating about CSR. Available at: http://ec.europa.eu/enterprise/policies/sustainablebusiness/files/csr-sme/communication_guide en.pdf. Accessed 12.10.14.

Fidelity Bank, (2013). Fidelity bank 2013 annual report. Avaialable at: http://www.fidelitybank.com.gh/media/photos/reports/2013\%20 Annual \%20Financials.pdf. Accessed on 01/10/2014.

Ghana commercial Bank limited, (2013). Supporting the aspirations of Ghana for 60 years, 2013 annual report. Available at: https://www.gcbbank.com.gh/images/docs/reports/2013 annualreport.pdf. Accessed on 01/10/2014.

Global Reporting Initiative (GRI). (2013). CSR communication on progress. London: GRI. Available at: http://static.globalreporting.org/ report-pdfs/2014/14b0816366eed61e2e74af1b18b673a5.pdf. Accessed 15/10/2014

Goodman, M. B. (Ed.). (1994). Corporate communication: Theory and practice. SUNY Press.

Graafland, J., Smid, H., 2004. Reputation, corporate social responsibility and market regulation. Tijdchrift Econ. Manag. 49(2), 271-308.

Guthrie, J., \& Parker, L. D. (1990). Corporate social disclosure: A comparative international analysis. Advances in Public Interest Accounting, 3,159-176.

Guthrie, J., Cuganesan, S., \& Ward, L. (2008). Intellectual capital reporting media in an Australian industry. International Journal of Learning and Intellectual Capital, 5(1), 48-62.

Guthrie, J., Cuganesan, S., \&Ward, L. (2007). Extended performance reporting: Evaluating corporate social responsibility and intellectual capital management. Issues in Social and Environmental Accounting, 1(1), 1-25.

HDFC Bank, (2014). HDFC bank 2013-2014 annual report. Available at: http://www.hdfcbank.com/htdocs/common/pdf/corporate/HDFCAnnulaReport-2013-14.pdf. Accessed on 1/10/2014

IBEF (2014), Banking Sector in India, 2014. A Report For India Brand Equity Foundation (IBEF). Available at: http://www.ibef.org/ 
industry/banking-india.aspx . Accessed on 11/10/2014.

ICICI Bank, (2004). ICICI Bank 2013-2014 annual report. Available at: http://www.icicibank.com/managed-assets/docs/investor/annualreports/2014//CICI-Bank-Annual-report-FY2014.pdf. Accessed on 03/10/2014.

Jones, S., Frost, G., Loftus, J., \& van der Laan, S. (2005). Sustainability reporting: Perspectives on regulatory and professional initiatives across the Asia Pacific. Melbourne: CPA Australia.

Jones, S., Frost, G., Loftus, J., \& van der Laan, S. (2007). An empirical examination of the market returns and financial performance of entities engaged in sustainability reporting. Australian Accounting Review, 17(1), 78-87.

KPMG. (2011). Corporate responsibility survey 2011: Marching towards embracing sustainable development. Available at: https:/l www.in.kpmg.com/SecureData/aci/Files/Corporate-Responsibilty-Survey-Report.pdf. Accessed 08.09.14.

Kuper, Jo, and Martin Hojsik. "Poisoning the poor: electronic waste in Ghana." (2008).

Mohan, R. (2005). Financial sector reforms in India: policies and performance analysis. Economic and Political Weekly, 40.

Nielsen, A.E., Thomsen, C., 2007. Reporting CSR e what and how to say it? Corp. Commun. Int. J. 12(1), 25 e40.

O'Donovan, G. (2002). Environmental disclosures in the annual report: Extending the applicability and predictive power of legitimacy theory. Accounting, Auditing and Accountability Journal, 15(3), 344-371.

Patten, D. M. (1991). Exposure, legitimacy, and social disclosure. Journal of Accounting and Public Policy, 10, 297-308.

Patten, D. M. (2002). The relation between environmental performance and environmental disclosure: A research note. Accounting, Organizations and Society, 27, 763-773.

Podnar, K. (2008). Guest editorial—Communication corporate social responsibility. Journal of Marketing Communication, 14(2), 75-81.

Punjab National Bank, (2014). Punjab National Bank 2013-2014 annual report. Available at: http://pnbindia.in/new/Upload/English/ Financials/PDFs/PNBANNUALREPORT201314.pdf. Accessed on 02/10/2014.

PWC, (2014). 2014 Ghana Banking Survey. The Future of Banking in Ghana.What's next? Available at: http://www.pwc.com/en_GH/ gh/assets/pdf/gh-banking-survey-2014.pdf. Accessed on 21/09/2014.

Roberts, R. W. (1992). Determinants of corporate social responsibility disclosure. Accounting, Organizations and Society, 17(6), 595612

Standard Chartered Bank Ghana Ltd, (2013). Driving investment, trade and the creation of wealth in Ghana, annual report 2013. http://reports.standardchartered.com/annual-report-2013/pdf/2013-Annual-Report.pdf. Accessed on 01/01/2014. Accessed on 01/10/2014.

State bank of India, (2014). State Bank of India annual report. Available at: https://www.sbi.co.in/portal/web/corporate-governance/ annual-report-2013-14. Accessed on 27/09/2014.

Sweeney, L., \& Coughlan, J. (2008). Do different industries report corporate social responsibility differently? An investigation through the lens of stakeholder theory. Journal of Marketing Communication, 14(2), 113-124.

Tanner, D. F., \& Bane, R. K. (1988). CD-ROM: A New Technology with Promise for Education. Technological Horizons in Education, 16(1), 57-60.

Yongvanich, K., \& Guthrie, J. (2005). Extended performance reporting: An examination of the Australian mining industry. Accounting Forum, 29(1), 103-119. 